\title{
The Use of Constant Market Share (CMS) Model to Assess Brazil Nut Market Competitiveness
}

\author{
Giovanna Paiva Aguiar ${ }^{1}$, João Carlos Garzel Leodoro da Silva ${ }^{1}$, José Roberto Frega ${ }^{2}$, Lorena Figueira de Santana ${ }^{1}$, \\ \& Jaqueline Valerius ${ }^{1}$ \\ ${ }^{1}$ School of Forestry Engineer, University of Parana, Curitiba, Brazil \\ ${ }^{2}$ School of Applied Social Sciences, University of Parana, Curitiba, Brazil \\ Correspondence: João Carlos Garzel Leodoro da Silva, School of Forestry Engineer, University of Parana, \\ Curitiba, Brazil. Tel: 55-(41)-9118-6332. E-mail: garzel@ufpr.br
}

Received: April 5, 2017 Accepted: June 26, $2017 \quad$ Online Published: July 15, 2017

doi:10.5539/jas.v9n8p174 URL: https://doi.org/10.5539/jas.v9n8p174

The research is financed by CAPES and FUNPAR.

\begin{abstract}
This paper aims to evaluate the variation of market share explained by structural and competitive forces using the Constant Market Share (CMS) model. Assuming that a country should maintain its market share to keep competitive, the equation used in the model analyzes the export basket composition, exports destination, growth or shrinkage of the world market and the competitiveness effect. The overall loss of the Brazilian market share in a time series from 1998-2012 is given due to the barriers of potential European markets and reduction of the market growth of the product with shell. In a different way, the increase in exports of shelled nuts to markets with higher growth rates contributed to a favorable outlook for Bolivian and Peruvian markets, which had a market share gain on the period.
\end{abstract}

Keywords: international market, non-timber forest products, Amazon

\section{Introduction}

The Brazil's nut extraction had great importance on the economic, social and political formation of Amazon region. It is between the most commercialized products in the national and international market (Silva, Santos, Gama, Noce, \& Leão, 2013; Barbosa \& Moret, 2015). The extractivism and processing of the nuts sustains several communities from Amazon and moves their regional economy at the same time that promotes the forest conservation (Sá, Bayma, \& Wadt, 2008; Homma, 2012; Bayma, Malavazi, Fonseca Andrade, \& Wadt, 2014).

As the collect of nuts do not require the cut of trees, this activity is considered, virtually, without environmental impacts and directly connected to the tropical forest preservation (Wadt, Kainer, Staudhammer, \& Serrano, 2008; Santos et al., 2010; Newing \& Harrop, 2000; Zuidema, 2002).

Brazil nuts has some advantages among other non-timber forest products, such as low perishability, generation of a considerable quantity of employment and high international demand (Zuidema, 2002). According to Food and Agriculture Organization of the United Nations (FAO) (2000), the Brazilian nut trade has about US\$ 2.5 billion of annual turnover and accounts for $2 \%$ share.

Only three countries-Brazil, Bolivia and Peru—export Brazil nuts, being Bolivia and Brazil the largests. Although most of the trees are found in Brazil, Bolivia has a big harvest due to its lower labor costs. In a market well established with universal standardized specifications, transportation costs represent the major part of total costs and this value is added to transportation and shelling of nuts.

Despite the importance of the non-timber forest products (NTFP), there is a gap of studies about the role of these products as a source of regional economic growth (Stoian, 2000). There are challenges on the extractivism of Brazil nuts, not only about the social and ecologic aspects of the activity but also in the economic sphere.

Furthermore, this product has experienced a loss of international market share over the last year. The income generated from the extractivism of Brazil nut still is too low for the maintenance of the families that depend on 
that activity, which, in general, seek other activities such as agriculture and livestock as a way to complement it (Escobal \& Aldana, 2003).

On the other hand, competitiveness is seen as a key factor to achieve success in industries of a country inserted on an international scenario. Although there is no consensus about the concept of competitiveness, from the view of performance, it can be express as the capacity of a firm formulate and implement strategies that allow them enlarge or conserve a sustainable position on market (Fajnzylber, 1988; Santos et al., 2010; Almeida, 2010a; Farina, 1999; Ferraz, 1989).

The ability of a country to maintain and expand your participation on international market also contributes to elevate the level of income of your population (Fajnzylber, 1988). In this sense, studies about competitiveness allow the comparison between industries of a country, or the same industry among different countries, and those who present better patterns of world market.

Thus, it is possible to identify competitive advantages and disadvantages of the industry with the objective of subsidize decision-making both on elaboration of public and private policies as productive practices.

One of the methods used to analyze the competitiveness of a country or an external market sector is the Constant Market Share (CMS), considered a widely used index due to its ease of application and intuitive appeal. This model attributes the growth of exports to structural forces or to competitiveness (Richardson, 1971).

In this sense, the present paper aim to study the competitiveness of Brazil nuts in shell and shelled in the international market, identifying the determinant factors of competitivity on market through the CMS model.

\section{Material and Methods}

\subsection{Database}

For this study were collected data, from 1998 to 2012, of quantity (kg) and value (USD) of Brazil nut exports, in shell and shelled.

The period was chosen according to the availability of data collected in the UnComtrade database (2013), maintained by the Statistical Division of the United Nations. The unit price was calculated by dividing the value of exports by the quantity exported each year, according to Equation (1), suggested by Almeida, Bittencourt, Santos, Eisfeld, and Souza (2009):

$$
P=\frac{V V}{Q V}
$$

Where, $P=$ price (US $\$ / \mathrm{kg}) ; V V=$ total exports/imports (US $\$$ ); $Q V=$ total volume exported/imported $(\mathrm{kg})(\mathrm{m})$.

As consulted, the database of the Central Bank of Brazil (BCBr) (2013) provided the annual time series of nominal exchange rate in Brazil.

Already, the annual time series of the Consumer Price Index (CPI) was collected in the database of Federal Reserve Economic Data (FRED, 2013), so that the export data—in dollars - could be deflated.

\subsection{The Constant Market Share Model}

The model of constant market share was drawn up initially by Tyszynski (1951) and refined by Learner and Stern (1970), and Richardson (1971a, 1971b). The "rule of constant share", which led to the model, states that the country should maintain its market share to keep competitive. Therefore, differences observed in a certain time interval between the market shares - expected and the real market share-might be explained by structural and competitive forces (Leame \& Stern, 1970).

The CMS model defined by the equation 1 as in Leamer and Stern (1970) has structural forces represented by effects of the world market growth (a), the export basket composition (b), export destination (c), and the competitiveness effect (d):

$$
\Sigma\left(V^{1}-V^{0}\right)=r V^{0}+\Sigma_{i}\left(r_{i}-r\right) V_{i}^{0}+\Sigma_{i} \Sigma_{j}\left(r_{i j}-r_{i}\right) V_{i j}{ }^{0}+\Sigma_{i} \Sigma_{j}\left(V_{i j}{ }^{1}-V_{i j}{ }^{0}-r_{i j} V_{i j}{ }^{0}\right)
$$

(a)

(b)

Where,

$V^{0}=$ Exported value by country in the period $0 ; V^{1}=$ Exported value by country in the period $1 ; i=$ exported product; $j=$ Country destination of exports; $r=$ Rate of world exportation growth between periods 0 and 1 .

The first effect presented on the equation attributes the change of exports of a country to the growth or shrinkage of the world market (a). The second effect, export basket composition (b), considers which goods the country 
exports and the world market growth of these goods to explain the variation on exports. As a result, if the export basket is, mainly, composed by goods with growth rates higher than the average the effect will be positive.

Therefore, the effect of the destination of exports (c) will be positive if the country has exported more to fast growing markets and negative if the destinations of exports are stagnant markets. In this case, a market is considered stagnant when your growth rate is lower than the average global growth rate of the exports of the same product.

Finally, the competitiveness effect (d) is the residue of the equation. All the variation that cannot be assigned to the other factors will be a result of a gain or loss of competitiveness. Thus, the term competitiveness is used in substitution to all the others uncountable effects included in it, as technology, quality and product differentiation.

On this article, the export basket of each country was composed by Brazil nut with shell and shelled, therefore the export basket effect was considered on the analysis. Thereby, this effect will be positive to those countries who export the type of nut whose world exportation $\left(r_{i}\right)$ has grown more than the world average of both types $(r)$.

Table 1 below demonstrates some of the authors that used the CMS model in their studies.

Table 1. List of authors and publications utilizing constant market share (CMS) model

\begin{tabular}{|c|c|}
\hline Author (s) & Studies \\
\hline Amaral, Gomes, Coronel, \& Silva (2013) & Studied the competitiveness of Mercosur countries in the export of soybeans. \\
\hline Parapinski (2012) & $\begin{array}{l}\text { Examined the effects of global market growth, export destination and competitiveness by applying the } \\
\text { CMS method for exports of Brazilian wood furniture during the period 1991-2010. }\end{array}$ \\
\hline Sereia, Camara, \& Anhesini (2012) & Used as a method to study the competitiveness of Brazilian coffee production between 1990 and 2007. \\
\hline Skriner (2009) & $\begin{array}{l}\text { Analyzed the development of the competitiveness of the market and the agenda of exports of Austrian } \\
\text { goods 1990-2006. }\end{array}$ \\
\hline Wu, Wang, \& Lin (2016) & $\begin{array}{l}\text { Used the model CMS to analyze the factors that affect the changes in exports of primary forest } \\
\text { products in the US and China between } 2005 \text { and } 2012 \text {. }\end{array}$ \\
\hline Dieter \& Englert (2007) & $\begin{array}{l}\text { Analyze the competitiveness of the German forest industry sector against the background of the } \\
\text { international timber markets. }\end{array}$ \\
\hline Pandiella (2015) & $\begin{array}{l}\text { Spain's share of the global market for goods exports into competitiveness and structural effects (i.e. } \\
\text { the impact of specialization, either in product or geographical terms) over 1996-2013. }\end{array}$ \\
\hline Marini (2010) & Application of Constant Market Share Analysis for the Study of Firm Profitability \\
\hline Devereux et al. (2015) & Exchange Rate Pass-Through, Currency of Invoicing and Market Share \\
\hline Türkekul, Güden, Abay, \& Miran (2010) & $\begin{array}{l}\text { Used constant market share analysis to determine the competitiveness of Turkey, Spain, Italy, Greece } \\
\text { and Tunisia, i.e. the world's primary olive oil producers, in markets in the USA, Australia, Canada, } \\
\text { Brazil and Japan in the periods } 2000-2004 \text { and 2005-2008. }\end{array}$ \\
\hline Singh (2014) & $\begin{array}{l}\text { Investigates the major sources of India's exports performance during the post-liberalization period } \\
\text { (1991-2011) by using constant market share model. }\end{array}$ \\
\hline
\end{tabular}

\subsubsection{Period of Analysis}

To apply the CMS model, different authors adopt different criteria to define the years or periods to use on the analysis. Thus, while some choose to evaluate the CMS results from one year to another (Almeida, 2010; Parapinski, 2012), others use the average values from the periods composed by two or more years on the calculations (Carvalho, 1997; Sereia et al., 2002; Coelho \& Berger, 2004; Coronel, Machado, \& Carvalho, 2009; Silva et al., 2013; Dyadkova \& Momchilov, 2014).

This study used the period of three years, distributed equidistantly, from three to three years, during the data series of fifteen years (1998-2012). The three trienniums chosen correspond to important facts of the international market of Brazil nuts, such as:

Period 1: from 1998 to 2000 - On the year of 1998 the European Union established their maximum limits of aflatoxins by the EC 1525/98, on lower values than those practiced by other countries, such as USA and Brazil.

Period 2: from 2004 to 2006-In 2003 the European Union has restricted by the EC 493/03 the import of Brazil nuts with shell coming from Brazil. This regulation had impacts on the structure of international commerce of the product, and its effects may be seen on Brazilian exports, mainly from 2004. 
Period 3: from 2010 to 2012-In 2010 the European Union established new limits of aflatoxins to the Brazil nuts (EC 165/10), raising the maximum content allowed. This period corresponds yet to the beginning of recovery of global markets after the American economic crisis of 2008.

\section{Results}

The CMS results can be observed on Table 2 in percentage and on Table 3 in terms of absolute value. The effect that most contributed to the elevation of Brazilian exports of Brazil nuts, between the periods 1 and 2, was the world market growth, responding for $733,98 \%$ of positive variation (Table 3 ).

Another effect that contributed to the growth of Brazil exports on the same period was the destination of exports (Tables 2 and 3). According to Learner and Stern (1970), when this effect is positive means that the country has concentrated its exports on growing markets. In Brazil's case, this positive effect was mainly promoted by four countries: South Africa, Belgium, Russia and Bolivia.

The agenda effect, by your turn, contributed negatively to the growth of Brazilian exports on the first period (Tables 2 and 3). The explanation to this can be found on Table 4, which shows that the growth rate of world exports of in shell nuts $(-24 \%)$ was smaller than the growth rate of total world exports of nuts $(59 \%)$. As Brazilian companies export more of the product with shell, on the first period (1998-2000), the effect was negative.

Table 2. Percentage contribution of each constant market share effect to the variation in Brazilian exports between first and second triennium (1998-2000/2004-2006) and between second and third periods (2004-2006/2010-2012)

\begin{tabular}{lll}
\hline Periods & $\mathrm{P} 1-\mathrm{P} 2 *$ & $\mathrm{P} 2-\mathrm{P} 3 *$ \\
\hline Growth & $733,98 \%$ & $106,50 \%$ \\
Agenda of exports & $-459,85 \%$ & $-7,69 \%$ \\
Destination & $99,16 \%$ & $-1,09 \%$ \\
Competitiveness & $-273,29 \%$ & $-197,72 \%$ \\
\hline$\Sigma$ Effects & $100 \%$ & $-100 \%$ \\
\hline
\end{tabular}

Note. $\mathrm{P} 1=$ First period (1998-2000); P2 = second period (2004-2006); P3 = Third period (2010-2012).

Finally, the competitiveness effect was also negative for the Brazilian exportation of Brazil nuts between the first and second periods (Tables 3 and 4). This effect compares the growth of exports in the period to how they should have been if the country kept its quote on the market. Therefore, the negative competitiveness presented by Brazil between 1998-2000 and 2004-2006 indicates that the country did not kept its quote on market to some important countries. In this case, the downfall on exports of shelled nuts to US, Germany, United Kingdom and Spain pushed the value of this effect down.

Table 3. Contributions in dollars (\$) from each effect of constant market share for changes in value of brazil exports between periods 1998-2000 to 2004-2006 and 2004-2006 to 2010-2012

\begin{tabular}{lll}
\hline Periods & P1-P2 & P2-P3 \\
\hline Change in exports & $2.184 .470,98$ & $-11.604 .553,72$ \\
Growth effect & $16.033 .550,39$ & $12.358 .924,01$ \\
Agenda of exports effect & $-10.045 .202,96$ & $-892.615,84$ \\
Destination effect & $2.166 .137,41$ & $-126.568,46$ \\
Competitiveness effect & $-5.970 .013,85$ & $-22.944 .293,43$ \\
\hline
\end{tabular}

In turn, the CMS model, when applied to the second and third periods, demonstrated a reduction of US\$ 11,604,553.72 on Brazilian exports of nuts with shell (Table 3). This reduction was caused by the effects: agenda, destination and competitiveness that negatively contributed with $-7,69 \%,-1,09 \%$ and $-197,72 \%$, respectively (Table 2).

Although being negative, the agenda effect (US\$ -892,615.84) was smaller than it was on the first period, when reached US\$ $-10,045,202.96$ (Table 3$)$. This happened because besides the world growth rates $(42 \%)$ had not 
been so superior to shelled nuts (33\%), as occurred on first period (Table 4), the Brazilian companies exported, on average, more shelled nuts on the triennium of 2004-2006.

Table 4. Growth rates of Brazilian nuts exports in shell, shelled and total between periods 1998-2000 to 2004-2006 and 2004-2006 to 2010-2012

\begin{tabular}{|c|c|c|c|c|c|c|}
\hline \multirow{2}{*}{\begin{tabular}{|l|} 
Periods \\
Nut type
\end{tabular}} & \multicolumn{3}{|c|}{ P1-P2 } & \multicolumn{3}{|c|}{ P2-P3 } \\
\hline & In shell & Shelled & Total & In shell & Shelled & Total \\
\hline World & $-24 \%$ & $9 \%$ & $5 \%$ & $33 \%$ & $43 \%$ & $42 \%$ \\
\hline Brazil & $-23 \%$ & $48 \%$ & $8 \%$ & $24 \%$ & $81 \%$ & $-39 \%$ \\
\hline
\end{tabular}

Already the destination effect, that had been positive relatively to the preview period, was negative between 2004-2006 and 2010-2012 (Tables 2 and 3). Although Brazilian companies has exported to high growth rates markets, as Hong Kong, Peru and Netherlands, the value of exports was not enough to compensate the decay on growth rates of imports on some of main buyers such as USA and Bolivia.

Between second and third triennia, Brazil's competitiveness was negative again, but this time in bigger measure than on the first and second periods (Tables 2 and 3). Thus, the loss of Brazil's participation on market of countries as Netherlands and China in the market of product with shell, and USA, Netherlands, Australia, New Zealand and Spain on shelled nuts exports permitted a negative competitiveness of US\$ -22,944,293.43.

It is important to highlight that even though the CMS model is assigned to different effects the variation of a country exports on a time period, and gives a value to competitivity of the country in question, the model is not able to justify the reason of the raise or decline of competitiveness. So, by the formula that calculates the competitiveness effect, it is known that the difference on market share of a country that cannot be explained by none of the other effects is attributed to competitiveness, but what did this country to be more or less competitive in determined period?

Learner and Stern (1970) explain that the gain or loss of competitiveness can be simultaneously attributed both to factors from the point of view of demand and supply. Thus, from the demand point of view the authors mention the inflation of the exportation prices, the difference of quality between products of different countries, marketing efficiency of each one and the capacity to realize sales when they are demanded. Already, from the supply point of view they quote the difference on inflation and on the exchange rate of each country, availability of factors of production and the elevation or reduction on productivity.

\section{Conclusions}

The Brazilian exports were negatively affected by the export agenda effect and competitivity on the first interval and by agenda effect, destination and competitivity on the second sub period.

In view of this, it was concluded that it may be advantageous for Brazilian companies and, therefore, for Brazil, to gain a share in the market for shelled Brazil nut, which has a higher rate of growth in the international market.

By being more competitive in exports of higher value-added products, the country could be exporting the shelled product at a higher price, gaining more space in the international market and bringing more income and development to its territory, especially for the extractive communities that depend of the chestnut for its sustenance.

\section{References}

Almeida, A. N., Bittencourt, A. M., Santos, A. J., Eisfeld, C. L., \& Souza, V. S. (2009). Evolução da produção e preço dos principais produtos florestais não madeireiros extrativos do Brasil. Cerne, 15(3), $282-287$. https://doi.org/10.4336/2016.pfb.36.88.1049

Almeida, A. N. (2010). Comparação entre a competitividade do Brasil e Canadá para produção de madeira serrada. (Tese de Doutorado, Universidade Federal do Paraná, Curitiba).

Amaral, F. B., Gomes, M. F. M., Coronel, D. A., \& Silva, F. A. (2013). Exportações de soja em grãos dos países do Mercosul: Competitividade no mercado internacional. Revista de Administração, 11(19), 47-64.

Barbosa, M. A., \& Moret, A. S. (2015). Produção e comercialização da castanha do Brasil: economia e disponibilidade financeira. Revista Gestão \& Sustentabilidade Ambiental, 4(2), 413-428. https://doi.org/ 10.19177/rgsa.v4e22015413-428 
Baymai, M. M. A., Malavazi, F. W., Sá, C. P. D., Fonseca, F. L., Andrade, E. P., \& Wadt, L. H. D. O. (2014). Aspectos da cadeia produtiva da castanha-do-brasil no estado do Acre, Brasil. Ciências Naturais, 9(2), 417-426.

BCBol (Banco Central de Bolivia). (2013). Retrieved May 9, 2013, from http://www.bcb.gob.bo

BCBr (Banco Central do Brasil). (2013). Retrieved May 9, 2013, from http:/www.bcb.gov.br/pt-br/paginas/ default.aspx

BCRP (Banco Central de Reserva del Perú). (2013). Retrieved May 9, 2013, from http://www.bcrp.gob.pe

Carvalho, F. M. A. (1997). A dinâmica agroexportadora Brasileira: Mudança estrutural, vantagem comparativa e fontes de crescimento. Revista de Economia e Sociologia Rural, 35(1), 9-44.

Coelho, M. R. F., \& Berger, R. (2004). Competitividade das exportações brasileiras de móveis no mercado internacional: Uma análise segundo a visão desempenho. Revista FAE, Curitiba, 7(1), 51-65.

Coronel, D. A., Machado, J. A. D., \& Carvalho, F. M. A. (2009). Análise da competitividade das exportações do complexo soja brasileiro de 1995 a 2006: Uma abordagem de Market-Share. Revista de Economia Contemporânea, 13(2), 281-307. https://doi.org/10.1590/S1415-98482009000200005

Devereux, M. B., Tomlin, B., \& Dong, W. (2015). Exchange rate pass-through, currency of invoicing and market share (No. w21413). National Bureau of Economic Research. https://doi.org/10.3386/w21413

Dieter, M., \& Englert, H. (2007). Competitiveness in the global forest industry sector: An empirical study with special emphasis on Germany. European Journal of Forest Research, 126(3), 401-412. https://doi.org/ 10.1007/s10342-006-0159-x

Dyadkova, M., \& Momchilov, G. (2014). Constant Market Shares Analysis beyond the Intensive Margin of External Trade. Discussion Papers, 94.

Escobal, J., \& Aldana, U. (2003). Are non-timber forest products the antidote to rainforest degradation? Brazil nut extraction in Madre de Dios, Peru. Elsevier World Development, 31(11), 1873-1887. https://doi.org/ 10.1016/j.worlddev.2003.08.001

Fajnzylber, F. (1988). Competitividade internacional: evolución y lecciones. Revista de la CEPAL, 36, 7-24.

Farina, E. M. M. Q. (1999). Competitividade e coordenação de sistemas agroindustriais: Umensaio conceitual. Gestão e Produção, 6(3), 147-161. https://doi.org/10.1590/S0104-530X1999000300002

Ferraz, J. C., Kupfer, D., \& Haguenauer, L. (1995). Made in Brazil: Desafios competitivos para a indústria. Rio de Janeiro, RJ: Campus.

Finicelli, A., Sbracia, M., \& Zaghini, A. A. (2011). Disaggregated analysis of the export performance of some industrial and emerging countries. International Economics and Economic Policy, 8(1), 93-113. https://doi.org/10.1007/s10368-010-0174-8

FRED (Federal Reserve Economic Data). (2013). Retrieved May 15, 2013, from https://fred.stlouisfed.org

Homma, A. K. O. (2012). Extractivismo vegetal ou plantio: Qual a opção para a Amazônia? Estudos Avançados, 740(26), 167-186. https://doi.org/10.1590/S0103-40142012000100012

Leamer, E. E., \& Stern, R. M. (1970). Quantitative international economics. Chicago: Aldine.

Marini, G. (2010). An application of constant market share analysis for the study of firm profitability. MPRA Paper, 25814. Retrieved from https://mpra.ub.uni-muenchen.de/25814

Newing, H., \& Harrop, H. N. (2000). European health regulations and Brazil nuts: implications for biodiversity conservation and sustainable rural livelihoods in the Amazon. Journal of International Wildlife Law \& Policy, 3(2), 109-124. https://doi.org/10.1080/13880290009353951

Pandiella, A. G. (2015). A Constant market share analysis of Spanish goods exports. OECD Economics Department Working Papers, 1186. https://doi.org/10.1787/5js69lb4b5mt-en

Parapinski, M. L. (2012). Desempenho das exportações brasileiras de móveis de madeira-1991 a 2010 (Dissertação de Mestrado, Universidade Federal do Paraná, Curitiba). Retrieved from http://www.floresta. ufpr.br/defesas/pdf_ms/2012/d614_0799-M.pdf

Richardson, J. D. (1971). Some sensitivity tests for a "Constant-market-shares" analysis of export growth. The Review of Economics and Statistics, 53(3). https://doi.org/10.2307/1937978 
Sá, C. P., Bayma, M. M. A., \& Wadt, L. H. O. (2008). Coeficientes técnicos, custo e rentabilidade para a coleta de castanha-do-brasil no Estado do Acre: sistema de produção melhorado. Rio Branco: Embrapa Acre.

Santos, J. C., Sena, A. L. S., \& Rocha, C. I. L. (2010). Competitividade brasileira no comércio internacional de castanha-do-brasil. XLVIII Congresso Brasileiro da SOBER, Anais... Campo Grande, 2010.

Sereia, V. J., Camara, M. R. G., \& Anhesini, J. A. R. (2012). Competitividade do complexo cafeeiro: Uuma análise a partir do Market Share e das vantagens comparativas simétricas. Revista de Economia, 38(1), 07-34. https://doi.org/10.5380/re.v38i1.28757

Silva, A. A., Santos, M. K. V., Gama, J. R. V., Noce, R., \& Leão, S. (2013). Potencial do Extractivismo da Castanha-do-Pará na Geração de Renda em Comunidades da Mesorregião Baixo Amazonas, Pará. Floresta e Ambiente, 20(4), 500-509. https://doi.org/10.4322/floram.2013.046

Singh, K. A. (2014). Constant Market Share analysis of India's export performance. Foreign Trade Review, 49(2), 141-161. https://doi.org/10.1177/0015732514525190

Skriner, E. (2009). Competitiveness and specialisation of the Austrian export sector: A Constant-Market-Shares analysis. Institute for Advanced Studies. Retrieved from http://hdl.handle.net/10419/72686

Stoian, D. (2004). Cosechando lo que cae: La economía de la castaña (Bertholletia excelsa H.B.K.) en la Amazonía boliviana. In M. N. Alexiades, \& P. Shanley (Eds.), Produtos Florestales, Medios de Subsistencia y Conservación. Estudios de caso sobre sistemas de manejo de productos forestales no maderables (Vol. 3, pp. 89-116). CIFOR.

Türkekul, B., Günden, C., Abay, C., \& Miran, B. (2010). Competitiveness of Mediterranean countries in the olive oil market. New Medit, 9(1), 41-46.

Tyszynski, H. (1951). World Trade in Manufactured Commodities. The Manchester School, 19(3), 272-304. https://doi.org/10.1111/j.1467-9957.1951.tb00012.x

UnComtrade (United Nations Commodity Trade Statistics Database). (2013). Retrieved March 5, 2013, from http://comtrade.un.org

Wadt, L. H. O., Kainer, K. A., Staudhammer, C. L., \& Serrano, R. O. P. (2008). Sustainable forest use in Brazilian extractive reserves: Natural regeneration of Brazil nut in exploited populations. Biological Conservation, 141, 332-346. https://doi.org/10.1016/j.biocon.2007.10.007

Wu, J., Wang, J., \& Lin, W. (2016). Comparative Analysis of Primary Forest Products Export in the US and China Using a Constant Market Share Model. Forest Products Journal, 66(7-8), 495-503. https://doi.org/ 10.13073/FPJ-D-14-00077

Zuidema, P. A., \& Boot, R. G. A. (2002). Demography of the Brazil nut tree (Bertholletia excelsa) in the Bolivian Amazon: Impact of seed extraction on recruitment and population dynamics. Journal of Tropical Ecology, 18(01), 1-31. https://doi.org/10.1017/S0266467402002018

\section{Copyrights}

Copyright for this article is retained by the author(s), with first publication rights granted to the journal.

This is an open-access article distributed under the terms and conditions of the Creative Commons Attribution license (http://creativecommons.org/licenses/by/4.0/). 